\title{
Anxiety and depression in the preoperative period of cardiac surgery
}

\author{
Ansiedade e depressão no período pré-operatório de cirurgia cardíaca
}

Eduardo Tavares Gomes ${ }^{1}$, Simone Maria Muniz da Silva Bezerra ${ }^{1}$

Objective: to analyze the frequency of anxiety and depression in the preoperative period of cardiac surgery in the scientific literature. Methods: this is an integrative review, whose corpus of analysis consisted of 17 articles, in a search carried out on the platforms MEDLINE (Pubmed), SCOPUS, CUIDEN, and SciELO. Results: the highest prevalences were $41.5 \%$ for anxiety and $28.3 \%$ for depression. Most of the studies on anxiety were developed from 2011; nine cohorts evaluated the negative repercussion of preoperative pain anxiety, postoperative anxiety, postoperative morbidity and mortality in the follow-up of up to 7.6 years. Conclusion: most studies reported anxiety and depression as significant conditions in the preoperative period.

Descriptors: Anxiety; Depression; Preoperative Period; Thoracic Surgery; Nursing.

Objetivo: analisar na literatura científica a frequência da ansiedade e a depressão no período pré-operatório de cirurgia cardíaca. Métodos: trata-se de uma revisão integrativa, cujo corpus de análise foi composto por 17 artigos, em uma busca realizada nas plataformas MEDLINE (Pubmed), SCOPUS, CUIDEN e Scielo. Resultados: as maiores prevalências encontradas foram de $41,5 \%$ para ansiedade e $28,3 \%$ para depressão. A maioria dos estudos sobre ansiedade foi desenvolvida a partir de 2011, nove coortes avaliaram repercussão negativa da ansiedade pré-operatória na dor, ansiedade pós-operatória, morbidade e mortalidade pós-operatória em seguimentos de até 7,6 anos. Conclusão: os estudos encontrados referem, em sua maioria, a ansiedade e a depressão como condições significativas no período pré-operatório.

Descritores: Ansiedade; Depressão; Período Pré-Operatório; Cirurgia Torácica; Enfermagem.

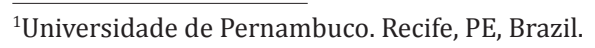




\section{Introduction}

Cardiac surgery has been linked to high rates of preoperative anxiety. The hospitalization for cardiological reasons already has great repercussion in the levels of anxiety, even non-surgical ones and even in the preoperative period. A study performed in a cardiology clinic shows the presence of anxiety in $76.7 \%$ of 30 patients who were not in the preoperative period ${ }^{(1)}$.

In surgical cases, in the preoperative period of general surgery, the presence of anxiety and depression measured by the Hospital Anxiety and Depression Scale (HADS) was evaluated in $44.3 \%$ and $26.6 \%$, respectively ${ }^{(2)}$. In a study carried out during the preoperative period of myocardial revascularization surgery, the anxiety and depression investigated with the same scale presented $34.4 \%$ and $28.1 \%$, respectively, reinforcing its high occurrence among hospitalized patients and, in particular, in those with cardiologic alterations with surgical indication, and the importance of the use of this scale in the early detection of these symptoms ${ }^{(3)}$.

Regarding the physiological repercussion of these mood states in the preoperative period, a study with 45 women in the preoperative period showed that anxiety increased heart rate in direct relation to the increase in the dose of propofol required for loss of consciousness, comparing their results to other studies that point to the same phenomenon ${ }^{(4)}$. Hypertension spikes at the time of surgery, evidenced in the operating room are also grounds for cancellation and are often associated with preoperative anxiety.

Recognizing anxiety and depression in patients awaiting surgery allows for the planning of appropriate interventions to improve such symptoms, individually, on one's needs, or even on health education groups, preparing patients for a surgical procedure ${ }^{(5)}$.

The review presented has the objective of analyzing in the scientific literature the frequency of anxiety and depression in the preoperative period of cardiac surgery to emphasize the relevance of the themes in the care practice and to provide subsidies for the understanding of the phenomenon.

\section{Methods}

This is an integrative review conducted to address the guiding question: "How often is anxiety and depression in the preoperative period of cardiac surgery?" Based on this question, it was desired to investigate not only incidence, as well as risk factors, coping and the correlation between the profile of the patients and the presentation of these disorders.

For the selection of the sample, the following databases were searched: Medical Literature Analysis and Retrieval System Online (MEDLINE), Scopus Info Site (SCOPUS), Bibliographic Database of the Foundation Index (CUIDEN) and Scientific Electronic Library Online (SciELO), In the period of October 2016. The databases and the library were chosen for their wide coverage. The descriptors/keywords used in the four databases and the electronic library were: preoperative period AND anxiety, preoperative period AND depression, cardiac surgery AND anxiety, cardiac surgery AND depression.

The articles were selected according to the following inclusion criteria: articles published in peer-reviewed journals on anxiety and depression in the preoperative period of cardiac surgery, with a sample of patients older than 18 years old; complete texts available in Portuguese, English or Spanish, indexed in databases and the electronic library. The studies considered were published from the 2000s, since in this decade the Hospital Scale of Anxiety and Depression was translated and validated into Portuguese as the main scale in the evaluation of anxiety in hospitalized 
patients and before this period, there was no specific scale for this purpose. The exclusion criteria were theses and dissertations; articles related to methodological research, such as the creation and/or validation of anxiety and depression instruments.

The selective reading of the articles found was initially performed with analysis by title and abstract and duplicate articles were recorded only once. An instrument was used to analyze the articles to ensure the registration of the set of relevant information and consonants to the guiding question, including identification data (published periodical, training and institution to which authors are linked, language and country), aspects (Survey design, sampling, data treatment), key findings and conclusions, and the characteristics of anxiety and depression surveyed.

Consequently, a detailed analysis of the articles was carried out, considering the accuracy and characteristics of the articles, following the registration of the information listed in the instrument. The information was interpreted, summarized and organized into a synthesis table, comparing the findings and finalized with propositions about the review.

\section{Results}

Only 17 of the 262 papers found in the search described compose the analysis corpus. For the time limit, 71 papers were excluded, 149 excluded by duplicate titles and abstracts, and 25 because they did not meet the objective of this study.

The studies were mostly international $(n=15)$, with cohort designs $(n=10)$ and only four randomized clinical trials, all evaluating educational interventions for patients in the preoperative period of cardiac surgery, aimed at reducing anxiety and depression. Cohort studies followed patients postoperatively at the intensive care unit, at the hospital, or for more than seven years after surgery ${ }^{(6-13)}$. One of the articles evaluated anxiety in correlation with stress, another important construct and not considered in the other studies $^{(13)}$.

Most studies on anxiety were developed from 2011, probably associated with a possible paradigm shift in health in which the psychological, emotional and social dimensions are considered relevant and constant interaction with biological aspects (Figures 1 and 2).

\begin{tabular}{|c|c|c|c|c|}
\hline Title & $\begin{array}{l}\text { Year/ } \\
\text { Country }\end{array}$ & Design/sample & Instrument & Results \\
\hline $\begin{array}{l}\text { Depression and anxiety in coronary artery } \\
\text { bypass grafting patients }{ }^{(14)}\end{array}$ & $\begin{array}{l}2003 \\
\text { Poland }\end{array}$ & $\begin{array}{c}\text { Cohort } \\
n=53\end{array}$ & $\begin{array}{l}\text { Spielberg Anxiety } \\
\text { Questionnaire (SAQ) } \\
\text { Beck Depression } \\
\text { Inventory (BDI) }\end{array}$ & $\begin{array}{l}\text { Moderate Anxiety }= \\
41.5 \% \text { and high }=13.2 \% \\
\text { Mild depression }=28.3 \% \\
\text { and moderate }=3.8 \%\end{array}$ \\
\hline $\begin{array}{l}\text { Depression, anxiety and neuropsychological } \\
\text { test scores of candidates for coronary artery } \\
\text { bypass graft surgery }\end{array}$ & $\begin{array}{l}2005 \\
\text { U.S. }\end{array}$ & $\begin{array}{l}\text { Cross-sectional } \\
\quad \mathrm{n}=60\end{array}$ & $\begin{array}{l}\text { Beck Depression } \\
\text { Inventory (BDI) and } \\
\text { State-Trait Anxiety } \\
\text { Inventory (STAI-T/S) }\end{array}$ & $\begin{array}{l}\text { BDI }=7.69 \pm 5.73 \\
\text { STAI-S } 40.29 \pm 10.56 \\
\text { STAI-T }=38.9 \%\end{array}$ \\
\hline $\begin{array}{l}\text { Preoperative patient education for open- } \\
\text { heart patients: a source of anxiety }{ }^{(16)}\end{array}$ & $\begin{array}{l}2006 \\
\text { Lebanon }\end{array}$ & $\begin{array}{l}\text { Quasi- } \\
\text { experimental } \\
n=110\end{array}$ & $\begin{array}{l}\text { Beck Anxiety } \\
\text { Inventory (BAI) }\end{array}$ & $\mathrm{BAI}=11.5 \pm 0.7$ \\
\hline $\begin{array}{l}\text { Anxiety predicts mortality and morbidity } \\
\text { after coronary artery and valve } \\
\text { surgery - a 4-year follow-up study }{ }^{(6)}\end{array}$ & $\begin{array}{l}2007 \\
\text { Hungrary }\end{array}$ & $\begin{array}{l}\text { Cohort } \\
\mathrm{n}=180\end{array}$ & BDI and STAI-T/S & $\begin{array}{c}\text { STAI-T }=44.6 \pm 10.0 \\
\text { STAIT-S }=44.8 \pm 11.4 \\
\text { BDI }=9.8 \pm 7.2\end{array}$ \\
\hline $\begin{array}{l}\text { Anxiety and depression as risk factors for } \\
\text { mortality after coronary artery bypass } \\
\text { surgery }{ }^{(7)}\end{array}$ & $\begin{array}{c}2008 \\
\text { Australia }\end{array}$ & $\begin{array}{l}\text { Cohort } \\
\mathrm{n}=440\end{array}$ & $\begin{array}{c}\text { Depression } \\
\text { Anxiety and Stress Scale } \\
\text { (DASS) }\end{array}$ & $\begin{array}{c}\text { Anxiety }=23.0 \% \\
\text { Depression }=20.0 \%\end{array}$ \\
\hline
\end{tabular}

Figure 1 - Characterization of the articles that composed the analysis corpus 


\begin{tabular}{|c|c|c|c|c|}
\hline Title & $\begin{array}{l}\text { Year/ } \\
\text { Country }\end{array}$ & Design/sample & Instrument & Results \\
\hline $\begin{array}{l}\text { Preoperative mood disorders in patients } \\
\text { undergoing cardiac surgery: risk factors and } \\
\text { postoperative morbidity in the Intensive } \\
\text { Care Unit }{ }^{(8)}\end{array}$ & $\begin{array}{l}2011 \\
\text { Spain }\end{array}$ & $\begin{array}{l}\text { Cohort } \\
n=100\end{array}$ & $\begin{array}{c}\text { Hospital Anxiety and } \\
\text { Depression Scale (HADS) }\end{array}$ & $\begin{array}{l}\text { Anxiety }=5.24 \pm 4.3 \\
(32.0 \% \text { anxious }) \\
\text { Depression }=3.60 \\
\pm 3.60 \text { (19.0\% of } \\
\text { depressives) }\end{array}$ \\
\hline $\begin{array}{l}\text { Randomized controlled trial of brief cognitive } \\
\text { behavioral intervention for depression and } \\
\text { anxiety symptoms preoperatively in patients } \\
\text { undergoing coronary artery bypass graft } \\
\text { surgery }{ }^{(17)}\end{array}$ & $\begin{array}{l}2011 \\
\text { U.S. }\end{array}$ & $\begin{array}{l}\text { Cohort } \\
n=100\end{array}$ & BDI eand & $\begin{array}{l}\text { STAI }- \text { Traço }= \\
55.8 \pm 11.8 \\
\text { BDI }=23.0 \pm 6.6\end{array}$ \\
\hline $\begin{array}{l}\text { A preoperative education interven- } \\
\text { tion to reduce anxiety and improve } \\
\text { recovery among Chinese cardiac patients: A } \\
\text { randomized controlled trial }{ }^{(18)}\end{array}$ & $\begin{array}{l}2012 \\
\text { China }\end{array}$ & $\begin{array}{c}\text { Randomized } \\
\text { Clinical Trial } \\
\mathrm{n}=153\end{array}$ & HADS & $\begin{array}{c}\text { Anxiety }=7.3 \pm 4.3 \\
\text { Depression }=5.9 \pm 4.3\end{array}$ \\
\hline $\begin{array}{l}\text { The impact of preoperative anxiety and } \\
\text { education level on long-term mortality after } \\
\text { cardiac surgery }\end{array}$ & $\begin{array}{c}2012 \\
\text { Hungrary }\end{array}$ & $\begin{array}{l}\text { Cohort } \\
n=180\end{array}$ & BDI and STAI-T/S & $\begin{aligned} \text { STATI-T } & =43.7 \pm 10.8 \\
\text { STAI }-S & =42.7 \pm 9.2 \\
\text { BDI } & =8.7 \pm 5.7\end{aligned}$ \\
\hline $\begin{array}{l}\text { Preoperative anxiety as a predictor of } \\
\text { mortality and major morbidity in patients } \\
>70 \text { years of age undergoing cardiac } \\
\text { surgery }{ }^{(10)}\end{array}$ & $\begin{array}{l}2013 \\
\text { U.S. }\end{array}$ & $\begin{array}{l}\text { Cohort } \\
n=148\end{array}$ & HADS & Anxiety $=7.3 \pm 4.3$ \\
\hline $\begin{array}{l}\text { The effect of a preoperative spiritual/ } \\
\text { religious intervention on anxiety in Shia } \\
\text { Muslim patients undergoing coronary artery } \\
\text { bypass graft surgery }{ }^{(19)}\end{array}$ & $\begin{array}{c}2013 \\
\text { Australia }\end{array}$ & $\begin{array}{l}\text { Randomized } \\
\text { Clinical Trial } \\
\quad \mathrm{n}=70\end{array}$ & $\begin{array}{c}\text { Hamilton } \\
\text { Anxiety Scale (HAS) }\end{array}$ & Anxiety $=31.0 \pm 5.4$ \\
\hline $\begin{array}{l}\text { Acolhimento e sintomas de ansiedade em } \\
\text { pacientes no pré-operatório de cirurgia } \\
\text { cardíaca }^{(20)}\end{array}$ & $\begin{array}{l}2014 \\
\text { Brazil }\end{array}$ & $\begin{array}{l}\text { Randomized } \\
\text { Clinical Trial } \\
\quad \mathrm{n}=66\end{array}$ & Nursing Diagnosis Anxiety & Anxiety $=8.91 \pm 3.05$ \\
\hline $\begin{array}{l}\text { Body affects mind? Preoperative behavioral } \\
\text { and biological predictors for postoperative } \\
\text { symptoms in mental health }\end{array}$ & $\begin{array}{l}2014 \\
\text { U.S. }\end{array}$ & $\begin{array}{l}\text { Cohort } \\
n=162\end{array}$ & STAI-T/S & STAI-S $=36.45 \pm 10.21$ \\
\hline $\begin{array}{l}\text { Preoperative and perioperative predictors } \\
\text { of reactive and persistent depression after } \\
\text { cardiac surgery: a three-month follow-up } \\
\text { study }{ }^{(12)}\end{array}$ & $\begin{array}{l}2014 \\
\text { Italy }\end{array}$ & $\begin{array}{l}\text { Cohort } \\
\mathrm{n}=134\end{array}$ & $\begin{array}{l}\text { STAI-T/S and Center for } \\
\text { Epidemiologic Studies of } \\
\text { Depression Scale - CESD }\end{array}$ & Depression $=28.0 \%$ \\
\hline $\begin{array}{l}\text { Can nurse-led preoperative education } \\
\text { reduce anxiety and postoperative } \\
\text { complications of patients undergoing } \\
\text { cardiac surgery? } \text { ? }^{(21)}\end{array}$ & $\begin{array}{c}2015 \\
\text { Greece }\end{array}$ & $\begin{array}{l}\text { Randomized } \\
\text { Clinical Trial } \\
\mathrm{n}=395\end{array}$ & STAI-T/S & $\begin{array}{l}\text { Anxiety }- \text { State }= \\
\quad 36.9 \pm 10.7\end{array}$ \\
\hline $\begin{array}{l}\text { Ansiedade no período pré-operatório de } \\
\text { cirurgia cardíaca }^{(22)}\end{array}$ & $\begin{array}{l}2016 \\
\text { Brazil }\end{array}$ & $\begin{array}{l}\text { Cross-sectional } \\
\mathrm{n}=106\end{array}$ & BAI & $\begin{array}{c}\text { Anxiety }=15.8 \pm 19.79 \\
(40.6 \% \text { Anxious })\end{array}$ \\
\hline $\begin{array}{l}\text { Evaluation of stress intensity and anxiety } \\
\text { level in preoperative period of cardiac } \\
\text { patientes }^{(13)}\end{array}$ & $\begin{array}{l}2016 \\
\text { Poland }\end{array}$ & $\begin{array}{l}\text { Cross-sectional } \\
\quad \mathrm{n}=58\end{array}$ & Own questionnaire & $\begin{array}{l}\text { Anxiety in correlation } \\
\text { with stress }\end{array}$ \\
\hline
\end{tabular}

Figure 2 - Characterization of the articles that composed the analysis corpus 


\section{Discussion}

These results of values for anxiety and depression found jointly point to a similar presentation of both. However, they are still questioned about a possible bias in instrument selection, since the scales that evaluate these constructs consider physiological signs and symptoms, except the Hospital Anxiety and Depression Scale, validated in inpatient populations and specific for this purpose, although with good specificity and moderate sensitivity ${ }^{(23)}$.

The presence of anxiety was recorded considered moderate in its majority, with the prevalence of up to $41.5 \%{ }^{(14)}$. On the other hand, depression appeared predominantly as mild, with a lower prevalence of up to $28.3 \%$ (Figure 1 ).

A national survey showed anxiety in scores considered to be high in $19.7 \%$ of the 106 preoperative patients evaluated, with mean anxiety being significantly higher in women than in men $(22,13 \pm 23,41$ versus $10,76 \pm 14,71 ; p=0,003)$. In this study, the presence of comorbidities did not alter anxiety scores. However, previous cardiac surgery experience elevated anxiety to high scores ${ }^{(22)}$.

In a study with 60 pre-ovarian myocardial revascularization patients, it was found that despite the high anxiety and depression scores, nor the combination of both was significant to negatively impact neurocognitive assessment. The neurophysiological tests of this study were affected only by age and education $^{(15)}$. However, the authors point out the limitation of not having a comparison with a control group in which no anxiety or depression was observed, requiring further studies to confirm whether or not the emotional aspects may lead to impairment of cognitive functions ${ }^{(15)}$.

In one of the articles, 162 patients were evaluated between 8 and 10 hours preoperatively and up to one month after cardiac surgery ${ }^{(11)}$. In the preoperative period, besides to the interviews, samples were collected to evaluate cortisol, C-reactive protein, and interleukin-6, while in the postoperative period, symptoms of mental health were evaluated, such as depressed mood, anxiety and hostility-irritability. Increased interleukin- 6 was associated with more depressed mood, and high cortisol was a predictor of hostility. The authors also found that comorbidities increased anxiety and that, in turn, anxiety further accentuated the relationships between markers and postoperative factors ${ }^{(11)}$. In this article, the authors present other references in an attempt to explain the phenomenon through the new evidence in the field of psychoneuroimmunology, in particular about cardiovascular diseases and its relation to stress hormones, the hypothalamic-pituitary axis ${ }^{(11)}$.

Among the articles selected, some pointed to the fact that preoperative anxiety is directly related to postoperative anxiety. Cohort studies showed similar results in this direction ${ }^{(6-13)}$.

One of the studies showed that anxiety and depression in the studied sample $(n=58)$ were directly and linearly correlated with stress associated with heart disease, surgery and postoperative complications $^{(13)}$. In this study, related factors classified as intrapersonal (pain, disease, suffering) and extrapersonal or external (anesthesia, surgery, complications) were studied, being the ones that had the most negative impact on preoperative anxiety (raising their scores) disease, the surgery itself and postoperative complications ${ }^{(13)}$. Finally, the authors suggest that patient education and psychological support that favors coping strategies may reduce anxiety levels ${ }^{(13)}$.

In an article published in Spain, the results of a research with 100 patients were disclosed in the preoperative period of surgery, it was found that the preoperative anxiety significantly increases the postoperative pain and the consumption of analgesic, neither anxiety nor depression did worsen the mortality in intensive care and that both were related to the longer hospitalization time ${ }^{(8)}$. A national survey found postoperative pain for $53.8 \%$ of patients and anxiety in $19.2 \%$, presenting other studies with similar results 
but also did not investigate whether postoperative pain and anxiety were related to preoperative anxiety ${ }^{(24)}$.

A research publication of 440 patients at an average follow-up of 5 years and ten months showed that moderate preoperative anxiety increases the risk of postoperative mortality, although depression is not the same ${ }^{(7)}$. The authors also suggest that although depression alone did not increase risk, future studies should investigate the association between the two factors $^{(7)}$.

A survey of 148 patients over 70 years old who underwent coronary artery bypass grafting showed that, although only $7.0 \%$ had high anxiety, the risk of postoperative morbidity and mortality increased up to five times in this group of patients ${ }^{(10)}$. This study, despite having only a small group with anxiety considered high to compare with the rest of the sample, was used the Hospital Anxiety and Depression Scale, indicated for hospitalized patients because they did not have evaluation items based on physical signs and symptoms, Reducing the instrument selection bias that may overestimate the individual score and the mean, as a consequence.

Despite studies showing that the preoperative anxious state has an impact on the risks and postoperative mortality, two studies considered that the personality trait had a more significant impact on increasing the risk of postoperative mortality, including long term, than the anxious state. A cohort study of 180 patients for an average of 7.6 years showed that a greater personality trait was more significant in increasing risk and mortality than in the preoperative state alone ${ }^{(9)}$. It is suggested in this study that the anxiety trait and education should be considered as an increase in the risk of prostate surgical mortality ${ }^{(9)}$. Another study with a 4-year follow-up found similar results ${ }^{(6)}$.

Nursing is particularly interested in evaluating the relationship between the presence of mood disorders in the preoperative period with neurocognitive functions to evaluate how much the anxious or depressive state can influence the adaptation-coping process and in the educational actions Performed.

Reports of positive experiences with educational interventions have been made in Brazil and abroad, reaffirming how much it is necessary to recognize the demands of patients and their families, to elaborate educational approaches and to develop methods to evaluate these strategies.

Evidence shows that patients submitted to educational intervention have lower anxiety rates and even better outcomes. In China, a randomized clinical trial of 153 patients tested an educational intervention with leaflets and verbal guidance, finding a significant reduction in preoperative anxiety and depression, reducing the length of intensive care without reducing postoperative hospital stay ${ }^{(18)}$. In Greece, a similar study also found that it does not impact on the reduction of the length of hospital stay nor the complications in the intensive care unit ${ }^{(21)}$.

In a quasi-experimental study conducted in Lebanon, patients were divided into two groups, the first $(n=53)$ being considered as control and not subject to any special health education protocol. The intervention group $(n=57)$ received an educational intervention at admission and, on the eve of the surgery, were followed up by a visit to the intensive postoperative unit. The group that submitted to the intervention had greater results, indicating that the health education strategy should be well thought out and constantly rethought to be effective ${ }^{(16)}$.

Besides to health education interventions, others in the spirituality and religiosity área may be effective in managing preoperative anxiety. In a randomized clinical trial of 75 Muslim patients in the preoperative period of myocardial revascularization, the researchers offered the intervention group five 45-minute sessions of religious-spiritual training based on Islam. The intervention group had significantly lower anxiety scores than the control group ${ }^{(19)}$. Although this was the only work that considered the religious-spiritual dimension, it is a significant indication of these relationships, which should still be studied and translated into more integrative practices. 
This study had the limitation of not including any research bases other than those chosen, and a greater number of articles could be obtained. However, the selection of bases favored a better quality of the articles found. For nursing, the evidenced results provide subsidies for the promotion of health with an integral approach, without neglecting the psycho-spiritual aspects of the patient.

\section{Conclusion}

Most studies reported anxiety and depression as significant conditions in the preoperative period, with the highest prevalences found being $41.5 \%$. For anxiety and $28.3 \%$ for depression.

\section{Collaborations}

Gomes ET and Bezerra SMMS contributed to the design, analysis, interpretation of data, article writing, critical review of content and final approval of the version to be published.

\section{References}

1. Pereira JMV, Cavalcanti ACD, Santana RF, Cassiano KM, Queluci GC, Guimarães TCF. Diagnósticos de enfermagem de pacientes hospitalizados com doenças cardiovasculares. Esc Anna Nery. 2011; 15(4):737-45.

2. Marcolino JAM, Mathias LAST, Piccinini Filho L, Guaratini AA, Suzuki FM, Alli LAC. Escala hospitalar de ansiedade e depressão: estudo da validade de critério e da confiabilidade com pacientes no préoperatório. Rev Bras Anestesiol. 2007; 57(1):5262.

3. Carneiro AF, Mathias LAST, Rassi Júnior A, Morais NS, Gozzani JL, Miranda AP. Avaliação da ansiedade e depressão no período pré-operatório em pacientes submetidos a procedimentos cardíacos invasivos. Rev Bras Anestesiol 2009; 59(4):431-8.
4. Gras S, Servin F, Bedairia E, Montravers P, Desmonts $J M$, Longrois $D$, et al. The effect of preoperative heart rate and anxiety on the propofol dose required for loss of consciousness. Anesth Analg. 2010; 110(1):89-93.

5. Almeida SM, Souza EN, Azzolin KO. Efeito da orientação pré-operatória por grupo multiprofissional na ansiedade de pacientes submetidos à cirurgia cardíaca. Rev Enferm UFSM. 2013; 3(3):402-8.

6. Székely A, Balog P, Benkö E, Breuer T, Székely J, Kertai MD, et al. Anxiety predicts mortality and morbidity after coronary artery and valve surgery-a 4-year follow-up study. Psychosom Med. 2007; 69(7):625-31.

7. Tully PJ, Baker RA, Knight JL. Anxiety and depression as risk factors for mortality after coronary artery bypass surgery. J Psychosomatic Res. 2008; 64(3):285-90.

8. Navarro-García MA, Marín-Fernández B, CarlosAlegre V, Martínez-Oroz A, Martorell-Gurucharri A, Ordoñez-Ortigosa E, et al. Preoperative mood disorders in patients undergoing cardiac surgery: risk factors and postoperative morbidity in the intensive care unit. Rev Esp Cardiol. 2011; 64(11):1005-10.

9. Cserép Z, Losoncz E, Balog P, Szili-Török P, Husz A, Juhász B. The impact of preoperative anxiety and education level on long-term mortality after cardiac surgery. J Cardiothoracic Surg [Internet]. 2012 [cited 2016 Oct 13];7:86. Available from: https://cardiothoracicsurgery.biomedcentral. com/articles/10.1186/1749-8090-7-86

10. Williams JB, Alexander KP, Morin JF, Langlois Y, Noiseux N, Perrault LP, et al. Preoperative anxiety as a predictor of mortality and major morbidity in patients $>70$ years of age undergoing cardiac surgery. Am J Cardiol. 2013; 111(1):137-42.

11. Ai AL, Kabbaj M, Kathy LL. Body affects mind? Preoperative behavioral and biological predictors for postoperative symptoms in mental health. J Behav Med. 2014; 37(2):289-99. 
12. Patron E, Messerotti Benvenuti S, Palomba D. Preoperative and perioperative predictors of reactive and persistent depression after cardiac surgery: a three-month follow-up study. Psychosomatics. 2014; 55(3):261-71.

13. Rosiek A, Kornatowski T, Rosiek-Kryszewska A, Leksowski A, Leksowski K. Evaluation of stress intensity and anxiety level in preoperative period of cardiac patients. Bio Med Res Intl [Internet]. 2016 [cited 2016 Aug 13]. Available from:https://www. hindawi.com/journals/bmri/2016/1248396/

14. Rymaszewska J, Kiejna A, Hadryś T. Depression and anxiety in coronary artery bypass grafting patients. Eur Psychiatry. 2003; 18(4):155-60.

15. Tshushima WT, Johnson DB, Lee JD, Matsukawa JM, Fast KMS. Depression, anxiety and neuropsychological test scores of candidates for coronary artery bypass graft surgery. Arc Clin Neuropsychol. 2005; 20(5):667-73.

16. Deiyrmejian M, Karam N, Salameh P. Preoperative patient education for open-heart patients: a source of anxiety? Patient Educ Couns. 2006; 62(1):111-7.

17. Dao TK, Youssef NA, Armsworth M, Wear E, Papathopoulos KN, Gopaldas R. Randomized controlled trial of brief cognitive behavioral intervention for depression and anxiety symptoms preoperatively in patients undergoing coronary artery bypass graft surgery. J Thorac Cardiovasc Surg. 2011; 142(3):109-15.

18. Guo P, East L, Arthur A. A preoperative education intervention to reduce anxiety and improve recovery among chinese cardiac patients: a randomized controlled trial. Int J Nurs Stud. 2012; 49(2):129-37.
19. Hossieni M, Salehi A, Khoshknab MF, Rokofian MF, Davidson PM. The effect of a preoperative spiritual/religious intervention on anxiety in shia muslim patients undergoing coronary artery bypass graft surgery. J Holistic Nurs. [Internet]. 2013 [cited 2016 Dec 0]; 31(3):164-72. Available from: https://www.ncbi.nlm.nih.gov/ pubmed/23942577

20. Assis CC, Lopes JL, Nogueira-Martins LA, Barros ALBL. Acolhimento e sintomas de ansiedade em pacientes no pré-operatório de cirurgia cardíaca. Rev Bras Enferm. 2014; 67(3):401-7.

21. Kalogiani A, Almpani P, Vastardis L, Baltopoulos G, Charitos C,Brokalaki H. Can nurse-led preoperative education reduce anxiety and postoperative complications of patients undergoing cardiac surgery? Eur J Cardiovasc Nurs. 2016; 15(6):44758.

22. Gonçalves KKN, Silva JI, Gomes ET, Pinheiro LLS, Figueiredo TR, Bezerra SMMS. Anxiety in the preoperative period of heart surgery. Rev Bras Enferm. 2016; 69(2):374-80.

23. Castro MMC, Quarantini L, Batista-Neves S, Kraychete DC, Daltro C, Miranda-Scippa A. Validade da escala hospitalar de ansiedade e depressão em pacientes com dor crônica. Rev Bras Anestesiol. 2006; 56(5):470-7.

24. Ribeiro CP, Silveira CO, Benetti ERR, Gomes JS, Stumm EMF. Nursing diagnoses for patients in the postoperative period of cardiac surgery. Rev Rene. 2015; 16(2):159-67. 